\title{
Effect of Two Different Concentrations of Ropivacaine in Axillary Brachial Plexus Block in Terms of Block Characteristics - A Comparative Study
}

\author{
Saurin B Panchal', Pankti A Panchal ${ }^{2}$, Karishma D Mehta \\ ${ }^{1}$ Assistant Professor, Department of Anesthesiology, SCL hospital, NHL Medical college, Ahmedabad, ${ }^{2}$ Resident Doctor, Department of Anesthesiology, \\ SCL hospital, NHL medical college, Ahmedabad.
}

\section{Abstract}

Background: Peripheral nerve block holds an important place in regional anesthesia. Application of ultrasound guidance in nerve blocks had increased success rate and minimize chances of complications. Ropivacaine, newer local anesthetic with wider safety margin, is widely used now a days in peripheral nerve blocks. Aim of our study is to compare two different concentrations of ropivacaine $(0.5 \%$ and $0.75 \%)$ in axillary brachial plexus block in terms of block characteristics. Subjects and Methods: A prospective randomized study was carried out in total of 60 patients, all of them given ultrasound guided axillary brachial plexus block. All patients were randomized into group A $(0.5 \%$ ropivacaine, $25 \mathrm{ml})$ and group $\mathrm{B}(0.75 \%$ ropivacaine, $25 \mathrm{ml})$. Succes rate, onset/ duration of sensory and motor block, duration of postoperative analgesia and complications if any were noted. Results: Both groups were comparable in terms of demographic characterics. There was no significant difference in onset and duration of sensory and motor block, duration of analgesia and patient satisfaction for both groups. Conclusion: $0.5 \%$ ropivacaine and $0.75 \%$ ropivacaine, both are safe and effective in axillary brachial plexus block with no added advantage of $0.75 \%$ ropivacaine over $0.5 \%$ ropivacaine.

Keywords: Peripheral nerve block, Brachial plexus, Ropivacaine.

Corresponding Author: Dr. Saurin B Panchal, Assistant Professor, Anesthesiology department, SCL hospital, NHL medical college, Ahmedabad.

Received: June 2019

Accepted: July 2019

\section{Introduction}

Peripheral nerve blocks are important part of regional anesthesia techniques. Peripheral nerve block is injection of local anesthetic solution around nerve bundle resulting in analgesia and loss of sensory and motor function supplied by it. ${ }^{[1]}$ Advantage includes intra-operative hemodynamic stability, minimize postoperative pain and nausea/vomiting, reduce opioid requirements and hasten recovery. ${ }^{[2,3]}$ With help of nerve blocks, airway instrumentation associated with general anesthesia can be avoided in high risk patients. Ultrasound assistance had made peripheral nerve blocks an optimal tool in anesthetic management.

Axillary brachial plexus block is commonly used in forearm fracture surgeries due to its easy accesibility and relative safety. ${ }^{[4]}$ Surgical conditions and patient satisfaction are nearly comparable to that of general anesthesia. Ultrasound assistance provide real time imaging and local anesthetic distribution during block. $5^{1}$ USG guided axillary brachial plexus block has increased success rate, fewer chances of complications and favourable postoperative pain score. ${ }^{[6]}$ Various types of local anesthetics are used in peripheral nerve blocks depending on type and duration of surgeries and patient profiles. Ropivacaine, a newer amide local anesthetic is widely used in peripheral nerve block now-a-days. It provide advantage of differential blockage and long duration of pain relief. ${ }^{[7,8]}$ Ropivacaine has favourable patient safety profile compared to bupivacaine. Ropivacaine is less lipophilic so relatively lesser motor blockade. ${ }^{[8]}$

Aim of our study was to compare efficacy and safety of two different concentration of ropivacaine in axillary brachial plexus block in terms of onset and duration of sensory-motor blockade, hemodynamic changes and patient satisfaction.

\section{Subjects and Methods}

A prospective randomized double blind comparative study was carried out on total of 60 patients in our institute from Nov 2018 to Feb 2019.Patients of either gender, aged 30-50 years with ASA grade 1 or 2, posted for elective forearm fracture surgeries were included in our study.

Exclusion criteria

- $\quad$ Emergency surgeries / open grade fracture

- $\quad$ ASA grade 3 or 4

- Allergy to local anesthetics

- $\quad$ Bleeding disorders

- $\quad$ Local site infection

- $\quad$ Severe systemic disease

All patients included in our study were randomized in with 
0

sealed envelope technique. They were allocated into two study groups and had received drug according to study group. We had used fixed volume of $25 \mathrm{ml}$ ropivacaine in this study.

Group A - 0.5\% Ropivacaine, total volume $25 \mathrm{ml}$ (max dose $3 \mathrm{mg} / \mathrm{kg}$ )

Group B - 0.75\% Ropivacaine, total volume $25 \mathrm{ml}$ (max dose $3 \mathrm{mg} / \mathrm{kg}$ )

A meticulous preoperative examination was done for all patients in both study groups. Informed consent was taken from every patient. All patients were explained about procedure of USG guided axillary brachial plexus block. Baseline monitors (NIBP, pulse oxymetry and ecg) were applied and vitals were noted. All patients received premedication with inj. midazolam $1 \mathrm{mg}$. Axillary block was performed using Ultrasound guidance and study drug given aiming to block all nerves with intermittant negative aspiration for blood. Maximum volume used in block was calculated according to weight of patient and was noted. Time for onset of sensory block and motor block were recorded every $5 \mathrm{~min}$ till $30 \mathrm{~min}$

\section{Sensory block grading}

\begin{tabular}{|l|l|}
\hline Score & \\
\hline 0 & No block or normal sensation \\
\hline 1 & Analgesia or deceased sensation \\
\hline 2 & Anesthesia or no sensation \\
\hline
\end{tabular}

Motor block grading
\begin{tabular}{|l|l|}
\hline Score & \\
\hline 0 & $\begin{array}{l}\text { No block or full flexion extension movements of elbow wrist } \\
\text { fingers }\end{array}$ \\
\hline 1 & Paresis or movements of fingers only \\
\hline 2 & Paralysis or complete absence of movements \\
\hline
\end{tabular}

Patients were graded as successful block, partial blocks and failure at $30 \mathrm{~min}$ post-injection.

Successful block- onset and peak effect of sensory and motor blockage in surgical area

Partial block- onset was there but not reaching to peak effects requiring supplemental injection

Failure - no onset of sensory and motor blockage in surgical area requiring general anesthesia

Intraoperative vitals were recorded every $5 \mathrm{~min}$ from block injection till $30 \mathrm{~min}$ and then every $15 \mathrm{~min}$ till end of surgery. Total duration of sensory block and motor block were also recorded. Patients were observed for postoperative pain for 1 hourly for first $6 \mathrm{hrs}$ and then 2 hrly till 12 hours. Severity of post-operative pain was graded on 0-10 point VAS score.( 0 no pain, 10 worst pain).When VAS score was $>4$ at any time, injection diclofenac sodium $75 \mathrm{mg}$ was given i.m. as rescue analgesic. Time taken for first rescue analgesic was also noted. Complications and side effects (nausea, vomiting, local anesthetic toxicity, hypersensitivity and hematoma) if any were recorded during intra-operative and post-operative period. Patient satisfaction score $(0-4)$ was also recorded (0 -not satisfied at all, 4- very satisfied). All data of both study groups were collected and analysed with SPSS 17 software. Statistical methods (chi square test,student's t test and $\mathrm{z}$ test) were used to measure level of significance. A value for level of significance was set at $p$ $<0.05$.

\section{Results}

All 60 patients were studied statistically in respect to demographic variables hemodynamic parameters, onset/duration of sensory and motor block, time for first rescue analgesic and side effects.

Table 1: Demographic variables
\begin{tabular}{|l|l|l|l|}
\hline & Group A & Group B & P value \\
\hline Age (yrs) & $40.83 \pm 5.05$ & $40.36 \pm 4.82$ & 0.87 \\
\hline Sex (M/F) & $18 / 12$ & $20 / 10$ & 0.42 \\
\hline Weight (kg) & $67.46 \pm 4.80$ & $66.03 \pm 4.23$ & 0.22 \\
\hline ASA I / II & $22 / 8$ & $26 / 4$ & 0.20 \\
\hline $\begin{array}{l}\text { Duration of } \\
\text { surgery(min) }\end{array}$ & $76.36 \pm 9.09$ & $80.1 \pm 9.43$ & 0.12 \\
\hline
\end{tabular}

Table 2: Success rate of block $(p>0.05)$

\begin{tabular}{|l|l|l|}
\hline & Group A $(\mathbf{n}=30)$ & Group B $(\mathbf{n}=30)$ \\
\hline Successful & 29 & 30 \\
\hline Partial block & 1 & 0 \\
\hline Failure & 0 & 0 \\
\hline
\end{tabular}

There was no significant difference in all patients of both study groups in demographic characteristics, ASA grading and duration of surgery. Both groups were comparable in this regards ( $\mathrm{p}$ value $>0.05$ )

There was no significant difference in failure rate in both groups ( $\mathrm{p}$ value $=0.34$ ). Only one patient in group A had partial effect requiring supplemental injection.

Table 3: Onset of sensory and motor block

\begin{tabular}{|l|l|l|l|}
\hline & Group A & Group B & P value \\
\hline $\begin{array}{l}\text { Onset of sensory } \\
\text { block(min) }\end{array}$ & $7.40 \pm 2.07$ & $6.73 \pm 1.52$ & 0.15 \\
\hline $\begin{array}{l}\text { Onset of motor } \\
\text { block(min) }\end{array}$ & $14.80 \pm 2.78$ & $14.33 \pm 2.20$ & 0.47 \\
\hline
\end{tabular}

Table 4: Duration of sensory block, motor block and analgesia

\begin{tabular}{|l|l|l|l|}
\hline & Group A & Group B & P value \\
\hline $\begin{array}{l}\text { Duration of sensory } \\
\text { block(min) }\end{array}$ & $552.33 \pm 77.57$ & $\begin{array}{l}569.66 \pm \\
70.29\end{array}$ & 0.36 \\
\hline $\begin{array}{l}\text { Duration of } \\
\text { motor block(min) }\end{array}$ & $\begin{array}{l}513.20 \pm \\
73.13\end{array}$ & $519.86 \pm 71.94$ & 0.72 \\
\hline $\begin{array}{l}\text { Duration of } \\
\text { analgesia(min) }\end{array}$ & $\begin{array}{l}585.67 \pm \\
50.87\end{array}$ & $\begin{array}{l}610.67 \pm \\
60.48\end{array}$ & 0.08 \\
\hline
\end{tabular}

Table 5: Hemodynamic parameters

\begin{tabular}{|c|c|c|c|c|}
\hline & & Group A & Group B & $P$ value \\
\hline \multirow[t]{3}{*}{ Systolic BP } & Baseline & $\begin{array}{l}118.46 \\
\pm 16.23\end{array}$ & $\begin{array}{l}120.13 \\
\pm 14.35\end{array}$ & \multirow[t]{3}{*}{$>0.05$} \\
\hline & $\begin{array}{l}\text { After Block } \\
(0 \mathrm{~min})\end{array}$ & $\begin{array}{l}119.56 \pm \\
15.45\end{array}$ & $\begin{array}{l}121.45 \\
\pm 15.23\end{array}$ & \\
\hline & $\begin{array}{l}\text { Post-op(0 } \\
\text { min })\end{array}$ & $\begin{array}{l}118.34 \\
\pm 15.89\end{array}$ & $\begin{array}{l}121.56 \\
\pm 15.78\end{array}$ & \\
\hline \multirow[t]{3}{*}{ Diastolic BP } & Baseline & $82.56 \pm 8.45$ & $83.67 \pm 7.86$ & \multirow[t]{3}{*}{$>0.05$} \\
\hline & $\begin{array}{l}\text { After Block } \\
(0 \mathrm{~min})\end{array}$ & $84.36 \pm 7.89$ & $84.87 \pm 7.87$ & \\
\hline & $\begin{array}{l}\text { Post-op(0 } \\
\text { min })\end{array}$ & $84.48 \pm 7.42$ & $84.56 \pm 7.89$ & \\
\hline \multirow[t]{3}{*}{ Pulse rate } & Baseline & $78.56 \pm 9.56$ & $79.67 \pm 8.87$ & \multirow[t]{3}{*}{$>0.05$} \\
\hline & $\begin{array}{l}\text { After Block } \\
(0 \text { min })\end{array}$ & $79.76 \pm 9.12$ & $80.65 \pm 9.34$ & \\
\hline & $\begin{array}{l}\text { Post-op(0 } \\
\text { min })\end{array}$ & $79.34 \pm 8.45$ & $78.45 \pm 9.45$ & \\
\hline
\end{tabular}

There was no significant difference in onset of sensory and motor block in both study groups ( $p$ value $>0.05$ ). Both study 
0

groups were also comparable in regards to duration of sensory and motor block, difference is not statistically significant. Duration of analgesia and hence time for first rescue analgesic (VAS score $>4$ ) was slightly more in group $\mathrm{B}$ than group $\mathrm{A}$ with no significance difference ( $\mathrm{p}$ value $>0.05$ ).

There was no significant difference in hemodynamic variables in all patients during study period. Both groups were comparable in terms of systolic BP, diastolic BP and pulse rate preoperatively, immediately after block and postoperative period $(\mathrm{p}$ value $>0.05)$. There was slight increase in blood pressure and pulse rate after block in both study groups, difference was not statistically significant.

No patients in both study groups had any complication and side effects intraoperatively or postoperatively. Patient satisfaction score at postoperative $(0 \mathrm{~min})$ period was comparable in both study groups. Mean score was $3.20 \pm$ 0.45 in group $\mathrm{A}$ and $3.12 \pm 0.78$ in group $\mathrm{B}$.

\section{Discussion}

Regional anesthesia is important adjuvant and/or alternative to general anesthesia in various orthopedic surgeries9. Peripheral nerve blocks are useful in providing optimal intraoperative surgical anesthesia and postoperative pain control. Success of any nerve block depends upon cooperation of patient and skillful application of anesthetic knowledge. Peripheral nerve blocks provide sensory, motor and autonomic block with resultant less postoperative tissue edema and pain. ${ }^{[1,10]}$ Main advantage of peripheral nerve blocks is better postoperative pain control with resultant early recovery. ${ }^{[3]}$ Axillay brachial plexus block provide safe, effective and acceptable anesthesia for forearm orthopedic surgeries.

Various local anesthetics were used since long in peripheral nerve blocks. Recently ropivacaine is gaining much importance in various peripheral nerve blocks. Ropivacaine is newer long acting local anesthetic that is structurally related to bupivacaine8. Ropivacine is less lipophilic than bupivacaine accounting lesser cardiac and CNS toxicity. ${ }^{[8,11]}$ Ropivacaine has advantage of greater sensory motor differentiation. We had used ropivacaine in our study as a choice of local anesthetics. Gaurav et al8 also found that effects on peripheral nerve block were nearly comparable for ropivacaine and bupivacaine. Singely et $\mathrm{al},{ }^{[11]}$ also found that ropivacaine was atleast as effective as bupivacaine in terms of block characyerisctis. Ropivacaine may have some advantage in terms of onset and duration of block but this remains controversial.

Various concentrations of ropivacaine can be used in peripheral nerve block. It depends on type of surgery and site of administration. Commonly used concentrations in brachial plexus block are $0.375 \%, 0.5 \%, 0.75 \%$ for anesthesia and $0.2 \%$ for analgesia. ${ }^{[8]}$ We had used $0.5 \%$ and $0.75 \%$ concentration of ropivacaine in our study. Both were found to be effective in providing anesthesia forearm. Hofmann et al and Liisanantti $\mathrm{O}$ et al reavealed their study that effects 0.5 $\%$ and $0.75 \%$ ropivacaine were comparable to that of $0.5 \%$ bupivacaine in brachial plexus block. ${ }^{[12,13]}$ Usha et al, ${ }^{[10]}$ demonstrated in their study efficacy of $0.5 \%$ ropivacaine in brachial plexus block with or without clonidine. Cappelleri et al, ${ }^{[14]}$ had revealed in their study that efficacy of $0.75 \%$ ropivacaine with or without fentanyl for brachial plexus block. So concentrations of ropivacaine $(0.5 \%$ and $0.75 \%)$, we had used in our study were exceptionally rational.

We had used fixed dose ropivacaine in axillary brachial plexus block. The volume was set at $25 \mathrm{ml}$ in both study groups. Liao et al, ${ }^{[15]}$ revealed in their study that the median effective volume for usg guided brachial plexus block was $23.6 \mathrm{ml}(95 \%$ confidence interval,21.3 - $26.2 \mathrm{ml})$, which was comparable with our study.

Ropivacaine can be used in dose of $3 \mathrm{mg} / \mathrm{kg}$ max. ${ }^{[16]} \mathrm{We}$ had also used ropivacaine upto max limit of $3 \mathrm{mg} / \mathrm{kg}$.

Ultrasound guidance in peripheral nerve block has gaining popularity now- a-days. Ultrasound offer several advantage in dealing with anatomic variation, reduce local anesthetic dose, improve quality of block and minimize side effects. In our study, usg guided axillary block had success rate of $96.66 \%$. a study done by Site BD et al demonstrate that usg guided nerve blocks had success rate of $93.6 \%$ which also correlate with our study. Study done by Qin et al, ${ }^{[18]}$ also revealed that success rate with usg in axillay block was around $90 \%$. We founded that no patients in both study groups had complication or side effects related to procedure or local anesthetics( intra-arterial injection, intra-neural injection, nausea, vomiting, hypotension, allergic reactions or neurological/cardiac toxicity). This was may be due to use of ultrasound and careful selection of ropivacaine dose. Neena et al, ${ }^{[5]}$ also stated that ropivacaine had wider safety margin and use ultrasound had made minimal chance of complications and side effects. Dae et al, ${ }^{[6]}$ also demonstrated in their study that use of ultrasound in brachial plexus block had higher success rate and minimal chances of complications. These findings were in correlation with our observations.

In our study, we noted that onset of sensory block was $7.40 \pm$ $2.07 \mathrm{~min}$ and onset of motor block was $14.80 \pm 2.78 \mathrm{~min}$ for group A patients $(0.5 \%$ roipvacaine $)$. We also noted that duration of sensory block was $552.33 \pm 77.57 \mathrm{~min}$ and duration of motor block was $513.20 \pm 73.13$ min for group A patients $(0.5 \%$ roipvacaine $)$. Mcglade et al,${ }^{[19]}$ demonstrated in their study that $0.5 \%$ ropivacaine in axillary block had median onset time of 10-20 min and median duration 5.3 $8.7 \mathrm{hr}$ which were in correlation with our findings.

We noted that first rescue analgesic in group A Patients had $585.67 \pm 50.87 \mathrm{~min}$, which were in correlation with finding of Kumar $\mathrm{S}$ et al, ${ }^{[20]}$ who revealed that $0.5 \%$ ropivacaine in brachial plexus block had first rescue analgesic requirement at $557 \pm 58.99 \mathrm{~min}$.

In our study, we noted that onset of sensory block was $6.73 \pm$ $1.52 \mathrm{~min}$ and onset of motor block was $14.33 \pm 2.20 \mathrm{~min}$ for group B patients $(0.75 \%$ ropivacaine $)$. Patil et al, ${ }^{[7]}$ also revealed in their study 0.75 ropivacaine had onset time 4.84 \pm 0.65 and $10.8 \pm 50.79$ which were comparable to our findings. We also noted that duration of sensory block was $569.66 \pm 70.29 \mathrm{~min}$ and duration of motor block was 519.86 $\pm 71.94 \mathrm{~min}$ for group B patients (0.75\% roipvacaine), findings were comparable with various studies.

We noted that first rescue analgesic in group B Patients had $610.67 \pm 60.48 \mathrm{~min}$, which were in correalation with finding of Capellgiri $\mathrm{S}$ et al, ${ }^{[14]}$ who revealed that $0.75 \%$ ropivacaine 
in brachial plexus block had first recsue analgesic requirement at $9.1-13 \mathrm{Hr}(25$ th -75 th percentile $)$. Patil et al, ${ }^{[7]}$ also revealed that duration of analgesia for 0.75 ropivacaine in axillary block was $613.10 \pm 51.79 \mathrm{~min}$.

There were no significant changes in hemodynamic parameters throughout study period in both groups ( $\mathrm{p}$ value $>0.05$ ). In our study, both groups were comparable in terms of onset/duration of sensory and motor block, time for first rescue analgesic and patient satisfaction ( $\mathrm{p}$ value $>0.05$ ). Bertini L et al, ${ }^{[21]}$ also demonstrated in their study that no significant differences were found in two different concentrations of ropivacaine $(0.5 \%$ and $0.75 \%)$ in axillary brachial plexus block in regard to block characteristics.

\section{Limitations}

There were certain limitations of our study. We had used fixed volume dose of roipvacaine indepedant of body weights. It may affect results and findings. We had also limited dose of ropivacaine upto $3 \mathrm{mg} / \mathrm{kg}$, so patients with low weight or very high weight were excluded from our study. We had usg guided axillary plexus block and through knowledge of usg anatomy and experience may affect results of study. Hence data and results obtained in our study should be interpreted accordingly.

\section{Conclusion}

We can conclude from our study that $0.5 \%$ ropivacaine and $0.75 \%$ ropivacaine, both are effective and safe in axillary brachial plexus block in regards to block characteristics, postoperative analgesia and patient satisfaction. $0.75 \%$ ropivacaine does not offer any additional advantage over $0.5 \%$ ropivacaine in axillary brachial plexus block.

\section{References}

1. Sarfraj A, Ananda P V, Singh RP et al. Comparative study of efficacy of clonidine added to levobupivacaine and levobupivacaine alone in supraclavicular brachial plexus block for upper limb surgery. Int $\mathrm{J}$ of Cont Med Res 2014; 1(2):7-13

2. Moore JG, Ross SM, Williams BA. Regional anesthesia and ambulatory surgery. Curr Opin Anesthesiol 2013; 266:652-660

3. Nahel N, Rajnish K, Lina Saffour et al. Dexamethasone and clonidine, but not epinephrine, prolong duration of ropivacaine in brachial plexus blocks, cross sectional analysis in outpatient surgery setting. Pain Medicine 2017 ;18(10):2013-2026

4. Mukka M, Bangera A, Krishna P. Ropivacaine with or without dexmedetomedine in axillary brachial plexus block. Saudi J Anesth 2016; 10:38-44

5. Jain N, Khare A, Khandewal S et al. Buprenorphine as an adjuvant to $0.5 \%$ ropivacaine for ultrasound guided supraclavicular brachial plexus block: A randomized double blind prospective study. Indian J Pain 2017; 31:112-118

6. Dae G, Won K. Case series: ultrasound guided supraclavicular block in 105 patients. Korean J Anesthesiol 2010; 58(3):267-271

7. Patil KN, Singh ND. Clonidine as an adjuvant to ropivacaine induced supraclavicular brachial plexus block for upper limb surgeries. J Anesthesiol Clin Pharmacol 2015; 31(3)365-369

8. Gaurav K, Geeta C. Ropivacaine: A review of its pharmacology and clinical use. Indian J Anesth 2011; 55(2):104-110

9. Rambabu S, M Srinivas, M Santhi. A comparative study of clonidine vs dexamethasone as adjuvants with local anesthetic in supraclavicular brachial plexus block. J of Dental and Medical Sci 2018; 17(2):55-64

10. Bafina U, Yadav N, Mamta K et al. Comparison of $0.5 \%$ ropivacaine alone and in combination with clonidine in supraclavicular brachial plexus block. Indian J Pain 2015; 29:41-45

11. Singlyn FJ. Clinical application of ropivacaine for the upper extremity. Curr Top Med Chem 2001; 1(3):219-225

12. Hofmann K, Herbrich C,Seebaurer A et al.Ropivacaine $7.5 \mathrm{mgml}$ versus bupivacaine $5 \mathrm{mgml}$ for interscalene brachial plexus block: A comparative study. Anesth Intensive Care 2002; 30:331-337

13. Liisanantti O, Luukkonen J, Rosenbergh PH. High dose bupivacaine, levobupivacaine and ropivacaine in axillary brachial plexus block. Acta Anesthesiol Scand 2004; 48:601-606

14. Cappelleri G, Beccaria P, Casati A et al. 0.75\% ropivacaine and fentanyl for axillary brachial plexus block. Euro J of Anesthesiol 2001; 18(75)

15. Liao J, Zhang X. Optimal volume of ropivacaine for ultrasound guided retrograde infraclavicular brachial plexus block. Euro J of Anesthesiol 2011; $28: 111$

16. M Kayani, Azad A. Maximum recommended dose of ropivacaine. Br J of Anes 2013; 110(3)

17. Sites BD, Spence BC, Gallagher JD et al. Characterizing novice behavior associated with learning ultrasound guided peripheral regional anesthesia. Reg Anesth Pain Med 2007; 32:107-115

18. Qin Q, Yang D, Xie H et al. Ultrasound guidance improves the success rate of axillary plexus block :a meta-analysis. Braz $\mathbf{J}$ of Anesthesiol 2016; 66(2):115-119

19. MacGlade DP, Kalpokas MV, Mooney PH et al. A comparison of $0.5 \%$ ropivacaine and $0.5 \%$ bupivacaine for axillary brachial plexus block anesthesia. Anesth Intensive Care 1998; 26(5):515-520

20. Kumar S, Palaria S, Sinha AK et al. Comparative evaluation of ropivacaine and ropivacaine with dexamethasone in supraclavicular brachial plexus block for postoperative analgesia. Anesth Essays Res 2014; 8(2):202-208

21. Bertini L, Tagariello V, Mancini S et al. $0.75 \%$ and $0.5 \%$ ropivacaine for axillary brachial plexus block: a clinical comparison with $0.5 \%$ bupivacaine. Reg Anesth Pain Med 1999; 24(6):514-518

Copyright: (c) the author(s), publisher. Academia Anesthesiologica International is an Official Publication of "Society for Health Care \& Research Development". It is an open-access article distributed under the terms of the Creative Commons Attribution Non-Commercial License, which permits unrestricted non-commercial use, distribution, and reproduction in any medium, provided the original work is properly cited.

How to cite this article: Panchal SB, Panchal PA, Mehta KD. Effect of Two Different Concentrations of Ropivacaine in Axillary Brachial Plexus Block in Terms of Block Characteristics - A Comparative Study. Acad. Anesthesiol. Int. 2019;4(2):102-105.

DOI: dx.doi.org/10.21276/aan.2019.4.2.25

Source of Support: Nil, Conflict of Interest: None declared. 